\title{
Orthodox-Dominant
}

\section{Looking Through a Veil}

\section{Challenges and Perspectives of Interreligious Dialogue in Serbia}

\author{
Angela Ilić \\ Research Associate, Institute for German Culture and History of \\ Southeastern Europe, Ludwig-Maximilians-Universität München, Munich, \\ Germany \\ ilic@ikgs.de
}

\begin{abstract}
Identity construction processes in Southeastern Europe and particularly in Serbia have resulted in distinct ideals of identities that are perceived to be incompatible with each other. Such understanding makes it extremely difficult to overcome ethnic, linguistic or religious/confessional boundaries. Almost any interconfessional or interreligious contact is by its nature interethnic and vice versa. Interreligious dialogue therefore faces great challenges but is not impossible to achieve. In the article, highlights and failed attempts from the history of interreligious dialogue initiatives in Serbia and Yugoslavia are presented and perspectives for the future are explored.
\end{abstract}

\section{Keywords}

interreligious dialogue - Southeastern Europe - incompatibility - identity - orthodoxy 
According to the data collected in the population census of 2011, the Republic of Serbia is home to a little over seven million inhabitants, the overwhelming majority of whom identify themselves as Christians. Around $84 \%$ of the population claimed to be Orthodox, just under $5 \%$ Catholic and almost $1 \%$ Protestant. Muslims make up 3.1\% of the population; the number of Jews reached $0.01 \%$ and of followers of Eastern religions $0.02 \%$. While Orthodox Christians are spread out all over the country, the highest concentration of Catholics is in the northern part of the Autonomous Region of Vojvodina in the north of the country, where pockets of Protestants can also be found. The majority of Muslims live in three municipalities in the Sandžak region in the southwest of Serbia, bordering on Bosnia and Montenegro and also in the Bujanovac-Preševo area, directly on the border of Kosovo - however, the latter area, home to many Albanian-speaking Muslims, was not completely surveyed in the census. ${ }^{1}$

Living in a religiously and confessionally mixed milieu is nothing new for Serbia: Today's religious diversity is a result of waves of migration and flight, of conversions and intermarriage across several centuries, as well as that of the changing of political borders particularly during the 19th and 2oth centuries. The majority Serbian Orthodox Church celebrated 800 years of its autocephaly in 2019, dating back to 1219; many of the Muslims have been there since Ottoman rule was established in the Late Middle Ages; and the roots of the Jewish population can be traced back even further, to Roman times.

A primarily religious/confessional form of self-identification was typical in the entire Southeastern Europe region until well into the 19th century. Through the spread of various national movements, it was gradually replaced by other categories that were now deemed as primary: national and ethnic self-identification. The largest churches in the South Slavic lands, the Roman Catholic Church and the Serbian Orthodox Church, all played important roles in tying ethnic identification to a particular confessional identification beginning in the second half of the 19th century. This is how the currently typical modes of identification (Croat $=$ Catholic, Serb = Orthodox $)$ came about and the local church hierarchies began to see themselves as representatives of a given ethnic group or nation and began propagating and supporting a conjointment

1 Đurić/Tanasković/Vukmirović/Lađević, Etnokonfesionalni, pp. 181-183. 
of these two facets of identity. Interestingly, such forms of ecclesiastical selfunderstanding had been either foreign or shunned in both traditions. ${ }^{2}$

Each of these constructions is built upon a clear distinction from others, leaving no room for accepting narratives other than one's own, but instead essentially discrediting them. As a result, there are rival identities that are based on being completely incompatible with the other. Due to this form of entanglement of religious and ethnic identity, it follows logically that almost any interconfessional or interreligious contact is thus by its nature interethnic and vice versa. ${ }^{3}$

\section{Ecumenical Dialogue Initiatives}

Ecumenical dialogue and ecumenical relations are a precondition from a Christian point of view for dialogue with members of other religions. At the same time, in the context of Serbia, they also reflect many of the same challenges faced by interreligious dialogue efforts. Some of the initiatives and events facilitating contact and dialogue between Roman Catholics and Serbian Orthodox are therefore presented first.

The waves of opening caused by Vatican II were also felt in Yugoslavia, of which Serbia was part, and resulted in the first ever official meeting between leaders of the two major churches in the country in 1968. Beginning in 1974, a reoccurring ecumenical symposium took place with student participants from the Catholic theological colleges in Zagreb and Ljubljana and from the Orthodox Theological College in Belgrade, with representatives of other ecclesiastical training institutions and of the Islamic Community as guests. The meetings continued biannually until 1990. ${ }^{4}$

Since the 199os, several ecumenical efforts were initiated by organizations outside of Serbia, such as the World Council of Churches (wCC) or the Austrian Foundation Pro Oriente, which aims to bring Eastern and Western churches together and improve relationships among them. Churches and individuals

2 National Catholicism, such as the one dominant in Croatia (but also observable in Poland, for example) goes against the self-description of the Roman Catholic Church as a transnational church. In the Orthodox tradition, the idea of ethnophyletism has traditionally been considered a heresy.

3 I have written extensively on church-state relations in Serbia and on the fact that the current legislation in the country essentially prefers monoethnic religious communities, privileging them above ethnically mixed groups. See e. g. Ilić, On the Road towards Religious Pluralism.

4 For a brief overview of ecumenical and interreligious dialogue in socialist Yugoslavia see Bremer, Kleine Geschichte der Religionen, pp. 65-69. 
in Germany have played a particularly important part in attempting to bring Serbian Orthodox and Croatian Roman Catholic Christians together - not the least because of the large Serbian and Croatian communities in Germany. ${ }^{5}$ One of the key figures behind several initiatives, including the "Friedensgrund" summer camp, focusing on reconciliation, for young people from Southeastern Europe and other parts of the continent, was the Roman Catholic Bishop of Hildesheim, Josef Homeyer (1929-2010). ${ }^{6}$ He visited Serbia many times, held lectures and met with political and religious leaders, winning the trust of local dignitaries $^{7}$ and calling attention to the situation in Serbia in European ecumenical and political circles as President of the Commission of the Bishops' Conferences of the European Union (COMECE) between 1993 and 2006.

Relations with the European Council of Churches (CEC/KEK) also intensified especially during the years of the Yugoslav wars in the 199os. In February 1996, the Theological Faculty of the Serbian Orthodox Church in Belgrade hosted a conference titled "Ecumenical Dialogue on Reconciliation," organized by the CEC. The conference brought together representatives not only of the CEC, but also of the Council of European [Catholic] Bishops' Conferences (CCEE), the host Serbian Orthodox Church, and other churches from Serbia, Croatia and Bosnia. At the end of the conference, the participants issued a group statement, in which they committed themselves to undertaking and supporting reconciliatory actions. ${ }^{8}$ The meeting, which took place partly in preparation for the Second European Ecumenical Assembly (held in Graz, Austria, in June 1997), did not seem to have a significant or lasting effect on ecumenical relations within the host country.

A different level of involvement from local churches was required when the CEC held its general assembly in Novi Sad in 2018, and the Serbian Orthodox Church together with some of the traditional Protestant churches were named as co-hosts of the event. There were also many more local participants

5 The first Serbian Orthodox liturgy on German soil was celebrated in the Pow camp in Osnabrück in 1941. The Bishopric of Western Europe of the Serbian Orthodox Church was organized in 1969, with its seat in Germany. For more on the establishment and development of the Serbian Orthodox community in Germany see Kolundžić, Orthodoxe Serben in Deutschland, pp. $45^{-} 5^{\circ}$.

6 For more on Homeyer's engagement in Southeastern Europe, and particularly in the former Yugoslav sphere, see Ilić, Churches in the Face of Political and Social Transition, pp. 251-258.

7 In 2004, the Serbian Orthodox Church awarded Homeyer the Order of Saint Sava First Grade in recognition of the support he had given to the Church and Serbia.

8 The proceedings from the conference have been published as Ecumenical Dialogue on Reconciliation. 
mobilized in facilitating the general assembly, which also brought local Christians of different confessions closer together. ${ }^{9}$

Further involvement in international ecumenical initiatives and organizations have proliferated in recent years. Just to name a few examples, the Ecumenical Forum of European Christian Women held its general assembly in Soko Grad, Serbia in 2018. Members of the Serbian Orthodox hierarchy have been involved in the work of the worldwide Lutheran-Orthodox Joint Commission. In 2010, the Europe-wide organization Societas Oecumenica held its biannual consultation on the premises and at the invitation of the Serbian Orthodox Theological Faculty in Belgrade. ${ }^{10}$ How much these forms of participation have encouraged and positively affected ecumenical dialogue in Serbia itself is difficult to measure.

One particular series of ecumenical meetings (with an occasional interreligious component) must be mentioned separately: the "Serbien-Tagungen". These Serbian-German interchurch encounters were initiated in Germany by the German Bishops' Conference (DвK) and the Evangelical Church in Germany (EKD) and through nine conferences, participants exchanged ideas and shared their experiences about political, social and historical issues, including church-state relations, reconciliation, democratization, church and civil society and the like. Although limited to a relatively small circle of theologians and clergy representatives, these encounters nonetheless resulted in strengthening personal connections and relationships and produced specific outcomes of cooperation. ${ }^{11}$

Locally initiated conferences with an ecumenical component have also taken place. One of these was the Conference on the Contribution of the Churches to Religious, Cultural and International Cooperation on the Path toward European Integration, which was held in the towns of Subotica and Bečej in November 2004 and was organized by the Bačka Diocese of the Serbian Orthodox Church and the Roman Catholic Bishopric of Subotica. Participants included representatives from all of the traditional churches in Serbia, government officials and members of national minority councils and nongovernmental organizations. The official message from the conference called Christian churches to "fruitful dialogue and fraternal cooperation".12

9 The Serbian Orthodox Church also reported positively about the assembly on its website: www.spc.rs.

10 A selection of contributions from the conference has been published as De Mey/ Schuegraf, Mission und Einheit.

11 See Ilić, Churches in the Face of Political and Social Transition.

12 Message from the Conference on the Contribution of the Churches. The conference was featured prominently on the website of the Serbian Orthodox Church in both Serbian and English. 
Concerning ecumenical cooperation on the practical level, one ecumenical NGO, the Ecumenical Humanitarian Organization (EHO) with its seat in Novi Sad has been active in Vojvodina since 1993 and has organized a School of Ecumenism yearly since $2007 \cdot{ }^{13}$

Overall, in spite of overwhelmingly positive developments in recent years, there is not much in terms of a history or tradition of ecumenical dialogue that churches in Serbia can look back upon. Additionally, there is an anti-ecumenical stance in certain circles of the Serbian Orthodox Church. This stems in part from interpretations of the theological legacy of Bishop Dr. Nikolaj Velimirović (1881-1956) $)^{14}$ and of the works of Dr. Justin Popović (1894-1979), both of whom expressed an ambiguous attitude toward ecumenism during the 2oth century. ${ }^{15}$

A related issue that should not be left without mention is the general uneasiness with which Orthodox churches sometimes view the ecumenical undertaking, which emerged from Western Christianity during Modernity. The structures, topics and terminology of dialogue have thus been determined and dominated by Western concepts and articulations, which in many cases differ from Orthodox ones and are therefore difficult to relate to.

In spite of the challenges, there are also several positive examples of ecumenical cooperation at the local level in Serbia - with many but not all of them in Vojvodina - that are based mostly on good personal relationships among clergy. Among the most vocal advocates and practitioners of ecumenical cooperation in recent decades, the following were included: the late Serbian Orthodox theology professor and founder and head of the Christian Cultural Center, Archpriest Dr. Radovan Bigović (1956-2012); the Slovenian-born Roman Catholic Archbishop of Belgrade Stanislav Hočevar, who between 2004 and 2011 was also Chairman of the International Bishops' Conference of Saints Cyril and Methodius, uniting Dioceses and Archdioceses in Serbia, Kosovo, Montenegro and North Macedonia; and Dr. Irinej Bulović, Serbian Orthodox Bishop of Bačka, who is a member of the Joint International Commission for

13 Its current members are the Slovak Evangelical [Lutheran] Church of the Augsburg Confession in Serbia, the Reformed Christian Church in Serbia, the Methodist Church in Serbia, the Greek Catholic Church in Vojvodina, and the Evangelical Christian Church of the Augsburg Confession in Vojvodina-Serbia. The Serbian Orthodox Church was a founding member but left the organization after founding its own humanitarian organization, Čovekoljublje [Philanthropy].

14 Velimirović's collected works were reprinted in the 1990s and he was beatified by the Serbian Orthodox Church in 2003.

15 Popović was beatified in 2010 and as a professor of dogmatics he influenced many who hold high-ranking positions in the Serbian Orthodox hierarchy today. 
Theological Dialogue Between the Catholic Church and the Orthodox Church and of the Lutheran-Orthodox Joint Commission.

\section{$3 \quad$ Interreligious Dialogue Efforts}

The political leadership in socialist Yugoslavia considered religion and religious communities as ideological enemies. Religious policy alternated between outright persecution and brief periods of granting limited forms of freedom. However, the government often tried to manipulate religious communities and to stir up animosities among them, thereby weakening the general will for pan-religious or inter-religious efforts within the communities themselves. Since the breakup of Yugoslavia, all religious communities have been on a quest for finding their place and extending their influence in their respective societies following turmoil and conflict. ${ }^{16}$

With such a background, it is not possible to speak about in-depth interreligious dialogue. That is why in the following sections it will not be assumed that dialogue as such was always taking place. Instead, interreligious dialogue efforts and initiatives, which may or may not have led to qualitative dialogue encounters, will be identified and discussed.

Particularly the Bosnian war (1992-1995) brought to light the necessity of interreligious efforts on the road towards reconciliation and peacebuilding. Dialogue-oriented activities intensified, and local non-governmental organizations (among them most prominently, Abraham) were founded, fostering interreligious encounters and dialogue. ${ }^{17}$ One of the organizations expanded to Serbia as well, and in 2012 the Multireligious and Intercultural Center of Belgrade (Beogradski multireligijski i interkulturni centar, BEMIC) was established. The topics of reconciliation and of coming to terms with the past (often in connection to transitional justice) have become both catalysts and obstacles to interreligious dialogue. ${ }^{18}$ More about that will be discussed later.

Recent interreligious dialogue initiatives in Serbia have included conferences with the participation of high-level representatives, often at events organized or co-organized by the government. There have also been high-level meetings and symbolically important visits by religious dignitaries. In this

16 See e. g. Mojzes, Religious Liberties; Mojzes, Religious Human Rights; Ramet/Nihil, Religion, Politics and Social Change; Murzaku, Quo Vadis Eastern Europe.

17 For an overview of initiatives Balkanwide see Merdjanova/Brodeur, Religion as a Conversation Starter.

18 For more on reconciliation see Ilić, Zwischen verordneter Amnesie. 
way, in 2010 and 2011 Hanukkah was celebrated in the synagogue in Belgrade with guests from other religions present - among them Serbian Orthodox Patriarch Irinej, Bishop Irinej Bulović and one year Belgrade Mufti Muhamed Jusufspahić. Although such encounters send a clear signal of standing together and are therefore to be applauded, their impact has rarely filtered down to the grass roots level of believers and practitioners.

On 17 June 2010, the Interreligious Council of Serbia was formed at the initiative of the Ministry of Religious Affairs in Serbia. Envisioned as a permanent interreligious body, its members were the Minister of Religious Affairs, Serbian Orthodox Bishop of Bačka Irinej Bulović (who has been the representative of the Holy Synod of the Serbian Orthodox Church at ecumenical and interreligious forums), Roman Catholic Archbishop of Belgrade Stanislav Hočevar, Reis-ul-ulema Adem Zilkić and Rabbi Isak Asiel. The objectives of the Interreligious Council were the affirmation of religious freedom and culture, issuing public statements concerning the most important societal issues and organizing conferences and round table discussions around relevant topics.

More organically based encounters and attempts at dialogue have included a continuation of the Orthodox-Catholic theological student symposia and mutual visits, where in addition to the Christian theologians, also Muslim students and faculty from the Sandžak have been involved. These encounters were led for years by the already mentioned Orthodox professor of theology, Radovan Bigović. ${ }^{19}$ Bigović, known to the Serbian public as a representative of a moderate and relatively open Serbian Orthodoxy, died unexpectedly in 2012. ${ }^{20}$

In 2006, an internationally initiated but locally organized workshop on interreligious dialogue was held in Novi Pazar, with around 30 young participants from the Orthodox, Catholic, Protestant and Muslim traditions. One recent series of high-level interreligious and intergovernmental dialogues was initiated by Indonesia in 2011. In 2019, it was already the fourth meeting that took place, with additional activities having been held in between the formal encounters. $^{21}$

\footnotetext{
19 Bigović also taught ecumenism and authored the textbook Pravoslavna teologija ekumenizma [Orthodox Theology of Ecumenism].

20 In his booklet The Orthodox Church in 21st Century, Bigović presents a concise but passionate plea for ecumenism and for engagement in interreligious dialogue.

21 As surprising as this may sound, Indonesia seems to be on a broader international mission for spreading its tradition of "Pancasila": In 2010 they initiated a Hungarian-Indonesian interreligious dialogue in a very similar format, and as participants of the conference noted, they have been doing the same in other European countries, too, including Denmark.
} 
The dialogue between the Serbian Orthodox Church and the Islamic Community in Serbia has been made especially challenging by the legacy of the most recent wars in Bosnia-Herzegovina and Kosovo. The division caused by rival groups within the Islamic Community has made it even more difficult to engage in ongoing conversation. High-level representatives have contact with one another through broader forums, and meetings among students of Orthodox and Muslim theology have taken place. The future course of these relations will have a significant impact on moving forward or hindering reconciliation not only in Serbia, but also in the entire region.

Not only religious communities or the Serbian government have been involved in organizing interreligious encounters. The non-governmental sector has also been active, and it seems that interreligiously focused events with initiators such as the Belgrade Open School, the Novi Sad-based Center for the Imperial Research of Religion (CEIR) or the Konrad Adenauer Foundation have been able to attract scholars as well as participants from a broad spectrum within the religious communities themselves. ${ }^{22}$

Concerning interreligious presence in the media, the second program on state television, RTS 2, has been broadcasting a religious calendar since the mid-20oos, where the traditions and major holidays of the Abrahamic faiths are briefly presented and explained each day.

\section{Challenges to Interreligious Dialogue}

There are several challenges and obstacles to meaningful dialogue, a few of which will be discussed here:

- One of the central issues allowing for dialogue is a critical and self-critical reassessment of the past by each participant. Most efforts focusing on this in Serbia have ended unsuccessfully, including the government-initiated Yugoslav Commission for Truth and Reconciliation (2001-2003), where religious communities were also represented. A 1995 initiative by the Austrian Catholic organization Pro Oriente to write a new, cumulated religious history of the region with Orthodox, Catholic and Muslim representatives

22 The Belgrade Open School has interreligious dialogue as one of its main areas of research and has organized several conferences and published books on this subject. CEIR publishes the journal Religija i Tolerancija twice a year. The Konrad Adenauer Foundation has organized or financially supported a number of conferences and round table discussions on interreligious dialogue. 
produced no results as invitations to participate were simply ignored from the Orthodox and Catholic sides. ${ }^{23}$

The veils of history that have been heaped on top of one another in front of people's eyes and thereby blocking any clear vision include the following developments:

- "The 5oo years of Turkish yoke." The southern regions of Serbia were indeed under Ottoman Turkish rule for half a millennium, where Christians lived as dhimmi, members of a non-Muslim minority, and in addition to having to pay multiples in taxes compared to what Muslim subjects of the Ottoman Empire had to pay (and through that actually buying their way out of otherwise compulsory Ottoman military service), were also deprived of several opportunities and rights that their Muslim neighbors enjoyed, essentially being largely consigned to lower social classes.

- The fight for Serbian independence was closely tied to fighting Ottoman (Muslim) forces, therefore conversions of Slavs to Islam were seen as betrayal. Such demeaning and overwhelmingly negative views of Islam and of Muslim converts are being perpetuated up to this day, at times even in schoolbooks.

- The Fascist legacy in Croatia and in the formerly Yugoslav territories. The Independent State of Croatia was a Fascist puppet state in existence between 1941 and 1945 and carried out a concentrated policy against Jews, Serbs, Roma and many others. Serbian Orthodox citizens were pressured to convert to Catholicism and a very large number of them perished in concentration camps, the best-known being Jasenovac, which in Serbian collective memory has come to symbolize the attempted extermination of Serbs at the hands of Croats. The fact that Fascist heritage in Croatia has not only been critically reappraised, but is becoming viewed in increasingly positive terms in mainstream society and even in certain circles of the Roman Catholic Church in Croatia, is causing outrage in Serbia and deepening the chasm between the two nations. ${ }^{24}$ The problematic and entangled nature of this cluster of issues was particularly visible through the work of the Croatian-Serbian Joint Commission entrusted by Pope Francis with the task of exploring the controversial person and legacy of the late Archbishop of Zagreb Alojzije Stepinac, who has been placed on the path to sainthood by the Roman Catholic Church. Although able to create some mutual understanding, the work of the commission ended without any agreement. The members of the commission in their concluding statement commented on

23 Perica, Balkan Idols, p. 184.

24 For more on this topic see e.g. Milekic, Croatian Church; Radonic, Krieg um die Erinnerung. 
the too divergent interpretations of the person of Stepinac and his acts, as well as various historical developments and figures held by the two sides. ${ }^{25}$

- Attempts at denying and diminishing Serbian complicity in the Yugoslav wars of succession and in ethnic cleansing against Croats, Bosniaks, Kosovar Albanians are still widespread even among members of the political and religious hierarchy and represent a serious obstacle to dialogue. These are still very touchy issues and have not been sufficiently dealt with in constructively critical ways in Serbian society.

All of the above has come to shape the ways in which neighbors of other confessions and religions are perceived. They are measurable through religious distancing in the population ${ }^{26}$ and are even present in the educational system through textbooks, perpetuating in many cases offensive stereotypes ${ }^{27}$ or offering no critical reflection on controversial historical developments or events. The fact that even churches and religious communities often allow such offensive views to be expressed by the representatives (including clergy) without any consequences, throws large stumbling blocks on the path toward meaningful interreligious contact.

Further challenges include:

- Fostering a victim mentality. This is to be observed all across Southeastern Europe, not only in Serbia. Typically, this is centered on the claim that 'my' people group or religious group has always been the victim through history: 'We' were occupied by foreign powers, 'we' were not allowed to practice our religion, 'we' were persecuted for our faith, 'we' were viciously attacked, betrayed etc., so everything 'we' did was only out of self-defense.

- One subcategory of dealing with the past is the relationship to transitional justice. Particularly the International Criminal Tribunal for the Former Yugoslavia (ICTY) and its judgments have stirred up controversy and strengthened nationalist hardliners in their resistance to examining the events during the wars of the 1990s. ${ }^{28}$

- Finally, the growing radicalization of Muslims particularly since the 199os, which is being largely orchestrated by foreign agents and governments and

25 Joint Communiqué on the Mixed Commission: "The Commission reached the conclusion that various events, interventions, writings, silences and positions are still subject to various interpretations. In the case of Cardinal Stepinac, the prevalent interpretations given by, respectively, Croatian Catholics and Serbian Orthodox, still remain divergent."

26 See e.g. Kuburić, Religious Distance in Vojvodina.

27 For example, conversions of South Slavs to Islam were being credited to their feeblemindedness (maloumlje) in Serbian textbooks for history throughout the 199os.

28 An interesting take on the issue is presented in Perović, The Collapse of Transitional Justice in Serbia. 
is a phenomenon to be observed throughout the Balkan Peninsula. The once widely held idealized image of a peaceful and progressive "European Islam" as typified by Bosnian Muslims was shattered by the wars of the 199 os. $^{29}$ Additionally, the influx of Muslim refugees and asylum seekers into Serbia since 2015 has put a strain on societal tolerance for Muslims in general.

These are among the most significant hindrances to any meaningful interconfessional or interreligious interaction. Leonard Swidler, a pioneer in the field of interreligious dialogue, in his Dialogue Decalogue ${ }^{30}$ - ten important steps that each individual should take or be aware of in preparing themselves for participating in interreligious dialogue - posits that as long as each participant in a potential dialogue considers themselves to be the victim of others, no meaningful dialogue can take place. Instead, these issues of hurt and distrust must be addressed and worked on collectively as a preparatory step for dialogue. As long as views of others are tainted by deep-seated hatred, only preparatory steps towards dialogue can be taken.

In light of - and in spite of - the above listed challenges, there are also promising perspectives for interreligious dialogue in Serbia.

- Majority-minority dynamics play a role here, which is particularly visible through the example of the Roman Catholic Church in Serbia, which - as a small minority - is in general very eager to participate in dialogue with others. This is not the case in Croatia, where the Catholic-Orthodox ratio is the other way around (Catholics: 86\%, Orthodox: 4.44\%). ${ }^{31}$ The Protestants, particularly the small traditional Protestant minority (Lutherans and Reformed), are also by and large favorable toward ecumenical and interreligious dialogue.

- The potential for dialogue and dialogical thinking among members of the younger generations. There is already one generation that has grown up since the breakup of Yugoslavia. Although this may not be true for all of them, many among them are ready to leave the ethnocentric baggage behind and reach out to their coreligionists or even to representatives of other religions across ethnic, political and linguistic boundaries.

\footnotetext{
29 For more about the illusion of a "European Islam" see the works of Xavier Bougarel, e. g. Clyer/Bougarel, Europe's Balkans Muslims.

$30 \quad$ Swidler, The Dialogue Decalogue, pp. 1-4.

31 Stanovništvo prema narodnostii vjeri [The Population according the Ethnicity and Religious Affiliation].
} 
- Still, dealing with the past through critical and constructive assessment in each religious community remains important, so that the veils blocking clear view can be removed. Simply ignoring the past or willfully forgetting it - or falling prey to far-right interpretations of it - will not lead to a better understanding of self and others long term, and will in turn block efforts at reconciliation and cooperation.

- The potential for interreligious cooperation in the fields of humanitarian aid and social assistance.

- Traditional moral values. Traditionally oriented Orthodox Christians and observant Muslims have more in common than they may think: They are also connected through similar moral views, which could offer platforms for dialogue and practical ways of cooperation.

- Shared pilgrimages. There are pilgrimage sites in Serbia that have traditionally been the focus for diverse confessions or even religious traditions, among them most prominently the Roman Catholic church of Our Lady of Snow in Tekije, Vojvodina, which has been a pilgrimage destination for Catholics and Orthodox alike on 5 August each year. Similarly, there are churches and monasteries in Sandžak, among them Đurđevi stupovi, which have attracted both Orthodox Christians and Muslims. Such sites also have great potential of intentionally drawing visitors into dialogue with one another.

Final Observations

In lieu of a conclusion, let me offer a few final observations concerning interreligious dialogue in Serbia.

Ideally, initiatives for dialogue come from within, not from the outside and preferably not from "the West". Such events, as already mentioned, have made symbolic statements but rarely affected anyone beyond their closed circle of participants. In order for local initiatives to arise and multiply, capacity building is what first must be focused on. Already existing organizations and individuals should be supported and encouraged. Such NGOs most often rely too much on their founding person, which on the one hand allows for flexibility but on the other hand presents problems in the fields of financing, growth and succession in case of their death or for other reasons.

Interreligious dialogue efforts at some point should focus on being or becoming transregional and transnational. Only through reaching these dimensions can they have a lasting impact.

Due to the entanglement of religious-ethnic identification and the currently still very broad societal role of Orthodoxy, hybrid forms of dialogue - not 
purely theological but instead exploring religious-cultural, religious-social, religious-political issues - may bring much more success and should therefore be encouraged.

However, as the first step, groundwork must be laid in the form of breaking down stereotypes and striving to rise above ethnic differences. Only after these initial steps are taken, will it be possible to conduct meaningful in-depth interreligious dialogue in Serbia and to support the already existing positive initiatives.

\section{Biography}

Angela Ilić works as a research associate at the Institute for German Culture and History of Southeastern Europe in Munich. Her focuses include interreligious dialogue, the history of Southeastern Europe in the 19th and the 2oth centuries, religious minorities in Central and Southeastern Europe and national identity. In her current project, she explores ethnic and religious identity constructions in two diverse cities in the late Habsburg Monarchy: Rijeka and Maribor.

\section{Bibliography}

Bigović, Radovan: Pravoslavna teologija ekumenizma [Orthodox Theology of Ecumenism]. Belgrade: Hrišćanski kulturni Centar, 2010.

Bigović, Radovan: The Orthodox Church in 21st Century. Belgrade: Foundation Konrad Adenauer, Christian Cultural Center, 2009.

Bremer, Thomas: Kleine Geschichte der Religionen in Jugoslawien: Königreich Kommunismus - Krieg. Freiburg i. B.: Herder, 2003.

Clyer, Nathalie/Bougarel, Xavier: Europe's Balkans Muslims: A New History. London: C. Hurst \& Co., 2017 .

Conference on the Contribution of the Churches to Religious, Cultural and International Cooperation on the Path to European Integration. Belgrade: Information Service of the Serbian Orthodox Church, 24 November 2004, http://www.spc.rs/old//Vesti2004/11/24-11-04-e.html\#mes (date of last access: 02.09.2020).

Đurić, Vladimir/Tanasković, Darko/Vukmirović, Dragan/Lađević, Petar: Etnokonfesionalni i jezički mozaik Srbije. Popis stanovništva, domaćinstava i stanova 2011 [The Ethno-Confessional and Linguistic Mosaic of Serbia. The 2011 Census of Population, Households and Dwellings]. Beograd, 2014. 
De Mey, Peter/Schuegraf, Oliver (eds.): Mission und Einheit - Gemeinsames Zeugnis getrennter Kirchen? Tagungsbericht der 16. Wissenschaftlichen Konsultation der Societas Oecumenica. Leipzig, 2012.

Državni zavod za statistiku Republike Hrvatske: Stanovništvo prema narodnosti i vjeri, popis 2011. [The Population according the Ethnicity and Religious Affiliation, 2011 Census], https://www.dzs.hr/Hrv/censuses/census2o11/results/htm/Ho1_o1_12/Ho1_ o1_12.html (date of last access: 18.og.2019).

Ecumenical Dialogue on Reconciliation, Belgrade, 19-22 February 1996: Conference of European Churches; Theological Faculty, Serbian Orthodox Church. Geneva, 1996.

Ilić, Angela: On the Road towards Religious Pluralism? Church and State in Serbia, in: Religion, State and Society 33 (4/2005), pp. 273-313.

Ilić, Angela: Churches in the Face of Political and Social Transition: German-Serbian Ecumenical Consultations 1999-2009/Kirchen und der politisch-gesellschaftliche Wandel. Deutsch-serbische ökumenische Begegnungen 1999-20o9. Leipzig: Evangelische Verlagsanstalt, 2014.

Ilić, Angela: Zwischen verordneter Amnesie und verweigerter Aufarbeitung der Vergangenheit. Perspektiven der Versöhnung in den jugoslawischen Nachfolgestaaten, in: Urszula Pękala (ed.): Ringen um Versöhnung II. Versöhnungsprozesse zwischen Religion, Politik und Gesellschaft. Göttingen: Vandenhoeck \& Ruprecht, 2019, pp. 111-128.

Joint Communiqué on the Mixed Commission Experts for a Joint Review of the Figure of Cardinal Alojzije Stepinac, Archbishop of Zagreb, 13.07.2017, Press Office of the Holy See, https://press.vatican.va/content/salastampa/en/bollettino/pubblico/2017/o7/13/170713.html (date of last access: 17.09.2019).

Kolundžić, Radomir: Orthodoxe Serben in Deutschland als "Gastarbeiter" und ihre vermehrte Zuwanderung seit 1990, in: Thomas Bremer/Assad Elias Kattan/Reinhard Thöle (eds.): Orthodoxie in Deutschland. Münster: Aschendorff, 2016, pp. 45-50.

Kuburić, Zorica: Religious Distance in Vojvodina, in: Christian Moe (ed.): Images of the Religious Other. Discourse and Distance in the Western Balkans. Novi Sad: CEIR, 2008, pp. 219-231.

Merdjanova, Ina/Brodeur, Patrice: Religion as a Conversation Starter. Interreligious Dialogue for Peacebuilding in the Balkans. London/New York, NY: Continuum, 2009.

Milekic, Sven: Croatian Church Urged to Tackle "Fascist Sympathisers", in: Balkan Insight, https://balkaninsight.com/2016/05/10/croatia-s-catholic-church-easy-onfascist-sympathizers-05-09-2016/ (date of last access: 18.o9.2019).

Mojzes, Paul: Religious Liberties in Eastern Europe and the USSR: Before and After the Great Transformation. Boulder, CO: Columbia University Press, 1992. 
Mojzes, Paul: Religious Human Rights in Post-Communist Balkan Countries, in: John Witte/Johan D. Van der Vyver (eds.): Religious Human Rights in Global Perspective: Legal Perspectives. The Hague: Martinus Nijhoff Publishers, 1996, pp. 276-303.

Murzaku, Ines Angeli (ed.): Quo Vadis Eastern Europe? Religion, State and Society after Communism. Bologna: Longo Editore, 2009.

Perica, Vjekoslav: Balkan Idols: Religion and Nationalism in the Yugoslav States. Oxford/ New York, NY: Oxford University Press, 2002.

Perović, Bojan: The Collapse of Transitional Justice in Serbia, in: Balkan Social Science Review 6 (2015), pp. 43-59.

Radonic, Ljiljana: Krieg um die Erinnerung. Kroatische Vergangenheitspolitik zwischen Revisionismus und europäischen Standards. Frankfurt am Main: Campus Verlag 2010.

Ramet, Sabrina Petra/Nihil, Obstat: Religion, Politics and Social Change in East-Central Europe and Russia. Durham/London: Duke University Press, 1998.

Serbian Orthodox Church, www.spc.rs. (date of last access: 02.09.2020).

Swidler, Leonard: The Dialogue Decalogue: Ground Rules for Interreligious Dialogue, in:Journal of Ecumenical Studies 20 (1/1983), pp. 1-4. 